\title{
The effect of stocking density and the application of Nitrobacter as ammonia decomposer in aquaponics system of Clarias gariepinus with water spinach (Ipomoea aquatica)
}

\author{
A.S. Taragusti, P. Fpkunair and B.S. Rahardja
}

Faculty of Fisheries and Marine, University of Airlangga, East Java, Indonesia

\begin{tabular}{l} 
Article information \\
\hline Article history: \\
Received September 26, 2019 \\
Accepted November 13, 2019 \\
Available online March 15, 2021 \\
\hline Keywords: \\
African catfish \\
Water quality \\
Specific growth rate \\
Survival rate \\
FCR \\
\hline Correspondence: \\
P. Fpkunair \\
prayogofpkunair@ gmail.com
\end{tabular}

\begin{abstract}
This study aimed to determine the effect of Nitrobacter bacteria on specific growth rate (SGR), survival rate (SR), and feed convertion ratio (FCR) of African catfish (Clarias gariepinus) in aquaponics systems. The sample used was African catfish with a size of 5-7 $\mathrm{cm}$ as many as 720 individuals. The research method used was experimental design in the form of Completely Randomized Design (CRD). This study used 5 types of treatments with 4 repetitions. The P0 and P1 contain of 30 fish in each aquarium; 35 fish in P2; 40 fish in P3; and 45 fish in P4. The control group (P0) were treated without Nitrobacter administration and the other 4 intervention groups were given Nitrobacter $1 \mathrm{ml}$ with a density of $1 \times 10^{8} \mathrm{CFU} \mathrm{ml}{ }^{-1}$. The main parameters studied were SGR, SR and FCR of African catfish in different aquarium with different stocking densities. This research also studied the growth of water spinach (Ipomoea aquatica) also water quality conditions in aquaponics systems. The administration of Nitrobacter in aquaponics systems gave a significant effect on the SGR, SR, and FCR of catfish. The administration of Nitrobacter in an aquaponics system can give maximum effect if there are 45 fish stocking densities and $1 \mathrm{ml}$ Nitrobacter with a concentration of $1 \times 10^{8} \mathrm{CFU} \mathrm{ml}{ }^{-1}$.
\end{abstract}

DOI: 10.33899/ijvs.2019.126116.1243, @2021, College of Veterinary Medicine, University of Mosul.

This is an open access article under the CC BY 4.0 license (http://creativecommons.org/licenses/by/4.0/).

\section{Introduction}

The world of aquaculture is experiencing a rapid development. One of the supporting programs is the aquaculture promotion in various sectors by the Indonesian government. One sector that is being promoted is the freshwater aquaculture. Increased productivity of freshwater fisheries is a government program in welcoming the Minapolitan program (1). Catfish is a commodity of freshwater fish with a fairly high nutrient content. Production of African catfish (Clarias gariepinus) in Indonesia has increased rapidly. In 2004 African catfish production was 55,691 tons, and in 2014 African catfish production reached 543,774 tons with an annual increase of $29.62 \%$ (2).
Increasing catfish production required more cultivated land and water use (3). The technology that has been widely applied by farmers in many countries to overcome the problem of limited land is conducting cultivation with an aquaponics system (4). Aside from reducing the land and water use, aquaponics also increases business efficiency through the utilization of nutrients from feed waste and fish metabolism (4,5). Aquaponics constitutes a recirculation system that reuses water which has been used in fish farming with many kinds of filters, such as biological and unbiological filters. One of the plants that can be used is water spinach (Ipomoea aquatica). Water spinach has roots which are not strong and easy to maintain. It requires optimum $\mathrm{pH}$ of nutrient solution which is influenced by 
$\mathrm{HNO}_{3}, \mathrm{H}_{3} \mathrm{PO}_{4}$, and $\mathrm{H}_{2} \mathrm{SO}_{4}$ for its growth process (6). These nutrients are obtained by absorbing the existing nutrients through its root. In aquaponics systems, plants absorb nitrates in the waters. The use of water spinach in aquaponics systems is able to reduce nitrogenous fish waste (7).

Fish cultivation with high stocking densities may impair the water quality due to the accumulation of organic matter (8). Factors that cause poor water quality are the remnants of fish feces and feed scraps that are not consumed by fish and are left to pile up and turn into ammonia $\left(\mathrm{NH}_{3}\right)$. Ammonia is toxic and dangerous for the survival of fish. The toxic concentration of ammonia in a short period of time ranges from 0.6 to $2.0 \mathrm{mg} \mathrm{L}^{-1}$ (9). This condition may cause several health problems, such as gill damage, that will further affect feed utilization and growth rate (10-12). One of the effective effort to maintain water quality in aquaponics systems is by adding Nitrobacter bacteria, as these bacteria are suitable materials to improve ammonia decomposition in fish aquarium (12). Therefore, this study was conducted to determine the effect of the administration of Nitrobacter bacteria as ammonia decomposer and stocking density on catfish's' growth rate, survival rate, and feed conversion ratio in aquaponics systems.

\section{Material and method}

\section{Description of the study sites}

This research was an experimental study using Complete Randomized Design (CRD). This research was conducted at the Faculty of Fisheries and Marine, University of Airlangga, Surabaya, Indonesia on January $28^{\text {th }}$ until February $28^{\text {th }}$ 2018. The independent variable in this study was the density of fish. This study gave different stocking density in each group. The high number of fish would influence the water quality because of fishs' metabolic waste. The dependent variables were SGR, SR, and FCR of African catfish. SGR is a growth of fish in a certain time, which is shown by fish weight and lenght. It was influenced by water quality, the amount of fish wastes, and feed. SR is the one of parameters that shows the success of fish cultivation which is influenced by water quality. FCR is a feed effectivity indicator and becomes a parameter that uses for increasing fish food intake. There was a Nitrobacter addition as a control variable. Every group was given Nitrobacter as a decomposer for ammonia from fish metabolic wastes. These group would be given the same concentration of Nitrobacter.

\section{Sample}

The materials used were African catfish with a size of 5$7 \mathrm{~cm}$ as many as 720 fish and Nitrobacter (MSC HIMBIO UNAIR, Indonesia). There were 20 aquaria with $(35 * 25 * 25)$ $\mathrm{cm}$ long, wide, and height which was filled by local company water about $20 \mathrm{~cm}$ height $(17.5 \mathrm{~L})$. Fish were fed with commercial feed in the form of HI-PRO VITE 781-1 pellets (PT Central Proteina Prima Tbk, Indonesia) at 6 a.m and 6 p.m. These pellets consist of $31 \%-33 \%$ protein. The average of commercial feed for catfish contain of $28 \%-32 \%$ protein level (13). This meant that feed in this study was very optimal for catfish growth. The water spinach plants were 8$10 \mathrm{~cm}$ long. they derived from water spinach seeds that were sown on burnt husk for 2 weeks. They were harvested about $8-10 \mathrm{~cm}$. Furthermore, water spinach was put into a net pot, was made from a plastic cup that has been modified as a way for water entry. Each net pot contained 5-8 water spinach seeds. Burnt husk addition is one way to reduce the use of soil as planting media. After the water spinach were ready, they moved to the trays. There were about 8 water spinach which put in the tray above each aquarium.

\section{Materials}

This study used pump set with AT-105 types (Atman) for recirculation. This study also used thermometer Vivid Oval Broader type (Safety), pH meter pen type PH-009 (ATC), DO meter HI9146 (Hanna), digital scale FEJ-5K (Quttro), fish nets $20 \mathrm{~cm}$ (PAM), hose 1-meter type (Puso), and ruler $30 \mathrm{~cm}$ (Butterfly).

\section{Procedures}

This study used five types of treatment with four repetitions in each treatment. The control group got treatment without Nitrobacter addition in the aquarium. Nitrobacter was planted in a test tube the put in an incubator with a temperature of $30^{\circ} \mathrm{C}$ about 2-3 days for developing bacteria. Bacterial incubation caused the test tube become turbid. Furthermore, bacteria washed using a centrifuge three times for 15-20 minutes. After the centrifuge appears precipitate, $\mathrm{NaCl} 0.9 \%$ was added so that the bacteria separated from the media. Mc Farland control contained suspended bacteria using $\mathrm{NaCl} 0.9 \%$ solution until turbidity was obtained according to $1 \mathrm{Mc}$ Farland's standard or aquivalent to $1 \times 10^{8} \mathrm{CFU} \mathrm{ml}{ }^{-1}$. Bakteria were then countd using dilution formula $\mathrm{V}_{1} \times \mathrm{N}_{1}=\mathrm{V}_{2} \mathrm{XN}_{2}$. The calculation results showed that the ratio of $1 \mathrm{ml}$ bacterial suspension in liquid form in a microtube is $4: 1$, so it took $0.25 \mathrm{ml}$ of bacterial suspension and $0.75 \mathrm{ml}$ of $\mathrm{NaCl} 0.9 \%$. Nitrobacter was taken using a micropupette and blur tip and then pured into each aquarium except P0 group. The 4 intervention groups were added $1 \mathrm{ml}$ Nitrobacter with a density of $1 \times 10^{8}$

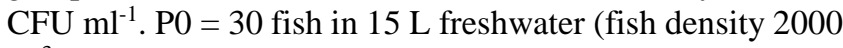
$\mathrm{m}^{-3}$ ) without Nitrobacter. P1 $=30$ fish in $15 \mathrm{~L}$ freshwater (fish density $2000 \mathrm{~m}^{-3}$ ) with $1 \mathrm{ml}$ Nitrobacter. $\mathrm{P} 2=35$ fish in $15 \mathrm{~L}$ freshwater (fish density $2300 \mathrm{~m}^{-3}$ ) with $1 \mathrm{ml}$ Nitrobacter. P3 $=40$ fish in $15 \mathrm{~L}$ freshwater (fish density $2600 \mathrm{~m}^{-3}$ ) with $1 \mathrm{ml}$ Nitrobacter. P4 $=45$ fish in $15 \mathrm{~L}$ freshwater (fish density $3000 \mathrm{~m}^{-3}$ ) with $1 \mathrm{ml}$ Nitrobacter.

The optimal stocking density of catfish was about 400 fish $\mathrm{m}^{-3}$ to 2400 fish $\mathrm{m}^{-3}$, so that they can grow well. The pattern of treatment aquarium was randomized to avoid bias.

It considered the bias of the treatment happened naturally; and also avoided impartialy to the one treatment. 
The main parameters studied were catfish specific growth rate (SGR), survival rate (SR) and feed conversion ratio (FCR). Whereas, the supporting parameters observed were water spinach plant growth and water quality conditions such as temperature, $\mathrm{pH}, \mathrm{DO}$ (dissolved oxygen), nitrite and nitrate in aquaponics systems. SGR is calculated based on individual weight gain per day with formula (14):

$$
\mathrm{SGR}=\frac{\ln \mathrm{W}_{\mathrm{e}}(\mathrm{g})-\ln \mathrm{W}_{\mathrm{s}}(\mathrm{g})}{\mathrm{d}(\text { days })} \times 100
$$

where: $\mathrm{SGR}=$ specific growth rate $(\% /$ day $)$;

$\mathrm{We}=$ mean of fish weight at the end of fish rearing $(\mathrm{g})$;

$\mathrm{Ws}=$ mean of fish weight at the beginning of fish rearing $(\mathrm{g})$;

$\mathrm{d}=$ total rearing days (day).

SR is calculated based on the number of catfish that can survive during observation in units of percent with formula (15):

$$
\mathrm{SR}=\frac{\mathrm{N}_{\mathrm{t}}}{\mathrm{N}_{0}} \times 100
$$

Where: $\mathrm{SR}=$ survival rate $(\%)$;

$\mathrm{Nt}=$ amount of fish in the end of fish rearing;

$\mathrm{Nt}=$ amount of fish in the beginning of fish rearing.

Whereas, FCR is calculated based on the Buwono's Equation (16):

$$
\mathrm{FCR}=\frac{\mathrm{F}}{\left(\mathrm{W}_{\mathrm{t}}+\mathrm{W}_{\mathrm{d}}\right)-\mathrm{W}_{0}}
$$

Where: FCR $=$ Feed Convertion Ratio;

$\mathrm{Wt}=$ weight of fish in the end of fish rearing $(\mathrm{g})$;

$\mathrm{Wd}=$ weight of dead fish during rearing $(\mathrm{g})$;

$\mathrm{W} 0=$ weight of fish in the first day of fish rearing $(\mathrm{g})$;

$\mathrm{F}=$ amount of feed $(\mathrm{g})$.

Measurement of supporting parameters, such as water spinach plant growth and water quality, were carried out manually. Measuring water spinach plants was done by using a ruler, from the base of the leaf to the tip of the leaf. On the other hand, $\mathrm{pH}$ and DO were observed every day in the morning at 7 a.m. The water temperature was recorded twice a day at 6 a.m and 4 p.m. However, ammonia, nitrite, and nitrate were analyzed once a week.

\section{Statistical analysis}

All data were analyzed using ANOVA (Analysis of Variance) test with SPSS Statistics 21 version. If there was a difference, it was followed by Duncan's multiple test with significant level 5\% (17).

\section{Results}

The results of calculating the SGR, SR and FCR of African catfish feed for 1 month can be seen in Table 1 .

Based on table 1, it can be seen that all treatments using Nitrobacter on P1, P2, P3, and P4 have higher SGR and SR value than control group. Whereas, the highest value of FCR was in the P0 treatment.

In figure 1, it can be seen that the highest SGR is found in treatment $\mathrm{P} 4$ which is equal to $5.0500 \%$ and the lowest is found in treatment $\mathrm{P} 0$ which is $2.8175 \%$.

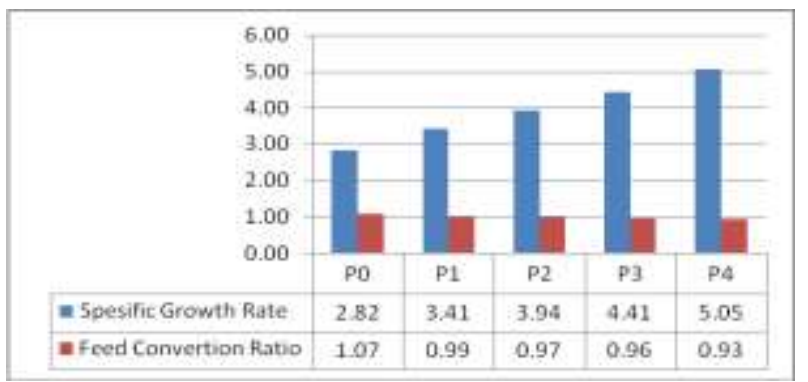

Figure 1: Graph of the average specific growth rate (SGR) and feed conversion ratio (FCR) of African catfish.

Whereas, the highest FCR was found in P0 treatment which was equal to 1.07 and the lowest was found in treatment $\mathrm{P} 4$ which was equal to 0.93 . In Figure 2 it can be seen that the highest SR was found in treatment P4 which was equal to $92.775 \%$ and the lowest was found in treatment P0 which was equal to $41.665 \%$.

Water quality data which includes temperature, $\mathrm{pH}, \mathrm{DO}$, ammonia, nitrite and nitrate in maintenance of african catfish can be seen in table 2 .

Data on water spinach growth rates, including water spinach length and number of leaves, in the maintenance of African catfish for 1 month can be seen in Table 3 .

Table 1: The average SGR, SR, FCR of African catfish

\begin{tabular}{cccc}
\hline \multirow{2}{*}{ Treatments } & \multicolumn{3}{c}{ Variables } \\
\cline { 2 - 4 } & SGR $( \pm$ SD $)(\%)$ & SR $( \pm$ SD $)(\%)$ & FCR $( \pm$ SD $)$ \\
\hline P0 & $2.8175 \pm 0.11087^{\mathrm{a}}$ & $41.665 \pm 8.81791^{\mathrm{a}}$ & $1.068450 \pm 0.0281757^{\mathrm{a}}$ \\
P1 & $3.4050 \pm 0.15111^{\mathrm{b}}$ & $68.330 \pm 4.30418^{\mathrm{b}}$ & $0.989700 \pm 0.0052814^{\mathrm{b}}$ \\
P2 & $3.9350 \pm 0.10376^{\mathrm{c}}$ & $75.710 \pm 1.65122^{\mathrm{c}}$ & $0.969650 \pm 0.0048707^{\mathrm{bc}}$ \\
P3 & $4.4125 \pm 0.11871^{\mathrm{d}}$ & $82.500 \pm 2.04124^{\mathrm{c}}$ & $0.956950 \pm 0.0114859^{\mathrm{c}}$ \\
P4 & $5.0500 \pm 0.07303^{\mathrm{e}}$ & $92.775 \pm 1.11000^{\mathrm{d}}$ & $0.927825 \pm 0.0115538^{\mathrm{d}}$ \\
\hline
\end{tabular}

Different superscripts show significant or non-significant differences $\mathrm{P}<0.05$. 
Table 2: The water quality average of African catfish maintenance

\begin{tabular}{lcccccccccccc}
\hline \multirow{2}{*}{$\mathrm{T}$} & \multicolumn{2}{c}{$\mathrm{DO}\left(\mathrm{mg} \mathrm{L}^{-1}\right)$} & \multicolumn{2}{c}{$\mathrm{pH}$} & \multicolumn{3}{c}{ Temperature $\left({ }^{\circ} \mathrm{C}\right)$} & \multicolumn{2}{c}{ Ammonia $\left(\mathrm{mg} \mathrm{L}^{-1}\right)$} & \multicolumn{2}{c}{ Nitrite $\left(\mathrm{mg} \mathrm{L}^{-1}\right)$} & \multicolumn{2}{c}{ Nitrate $\left(\mathrm{mg} \mathrm{L}^{-1}\right)$} \\
\cline { 2 - 13 } & $\mathrm{I}$ & $\mathrm{F}$ & $\mathrm{I}$ & $\mathrm{F}$ & $\mathrm{I}$ & $\mathrm{F}$ & $\mathrm{I}$ & $\mathrm{F}$ & $\mathrm{I}$ & $\mathrm{F}$ & $\mathrm{I}$ & $\mathrm{F}$ \\
\hline P0 & 3.58 & 2.17 & 8 & 8 & 28.8 & 28.4 & 0.24 & 0.27 & 0.04 & 0.06 & 1.77 & 1.59 \\
P1 & 3.28 & 1.53 & 8 & 7 & 28.4 & 27.4 & 0.23 & 0.15 & 0.04 & 0.03 & 1.77 & 2.79 \\
P2 & 3.18 & 2.19 & 8 & 7 & 28.3 & 27.3 & 0.22 & 0.14 & 0.04 & 0.02 & 1.78 & 2.76 \\
P3 & 3.09 & 2.27 & 8 & 7 & 28.8 & 27.5 & 0.21 & 0.13 & 0.04 & 0.02 & 1.80 & 2.87 \\
P4 & 3.01 & 1.42 & 8 & 7 & 28.5 & 27.4 & 0.19 & 0.12 & 0.04 & 0.02 & 1.83 & 2.93 \\
\hline
\end{tabular}

Initial calculation - week 0 , and final calculation - week 4; $\mathrm{T}=$ treatment; $\mathrm{I}=$ initial; $\mathrm{F}$ = final.

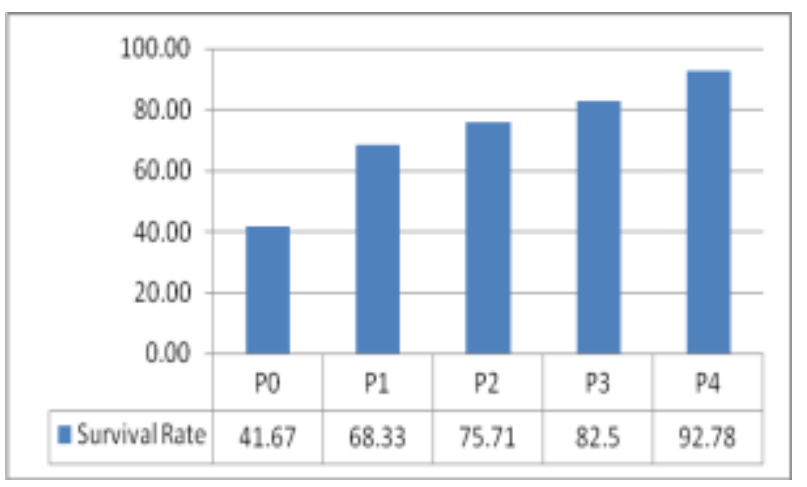

Figure 2: Graph of the average survival rate (SR) of African catfish.

Table 3: Average water spinach growth

\begin{tabular}{lcccc}
\hline \multirow{2}{*}{ Treatments } & \multicolumn{2}{c}{ Water spinach length $(\mathrm{cm})$} & \multicolumn{2}{c}{ No. of leaves } \\
\cline { 2 - 5 } & Initial & Final & Initial & Final \\
\hline P0 & 10 & 15.5 & 2 & 6 \\
P1 & 10 & 21 & 3 & 9 \\
P2 & 10 & 23 & 3 & 9 \\
P3 & 10 & 25.5 & 3 & 10 \\
P4 & 10 & 27.5 & 3 & 11 \\
\hline
\end{tabular}

\section{Discussion}

Nitrobacter addition in aquaponics systems affected the SGR of African catfish. This study showed each treatment groups (P1, P2, P3, and P4) had specific differences of SGR with control group (P0). The highest SGR was found in treatment P4 (5.05\%), while the lowest SGR was found in treatment P0 $(2.82 \%)$. It was caused by different water quality for each treatment. Residual energy from protein in P0 did not converted into fish weight, but it converted into fish lenght. There are several factors affect to SGR's catfish such as: fish type, genetic, feed, disease resistance, water quality, and stocking density (18). Fish emitted 80-90\% ammonia ( $\mathrm{N}$-inorganic) through the osmoregulation process, while from feces and urine, it is around 10-20\% of total nitrogen (19). P0 group had not got Nitrobacter treatment where ammonia concentration was accumulated. The high concentration of ammonia decreased water quality which affected to the catfish's cultivation. This condition triggered stress in fish and reduced feed intake (20). Long term of stress could influence fish's homeostatic also may impaired immune systems (12). Energy sources of African catfish changed into body weight because of the high of density and aquarium size. It was also helped by Nitrobacter which decreased the accumulation of ammonia and accelerated to water quality reparation (21). It converted nitrite into nitrate in fish metabolic wastes (12).

The administration of Nitrobacter also showed significant effect and significant differences on the catfish's SR $(p<0.05)$. SR as a parameter of fish's sustainability in a cultivation place (22). The highest SR was on P4 (92.77\%) and the lowest was found $\mathrm{P} 0$ (44.6\%). Intervention groups (P1, P2, P3, and P4) had a number of fish mortalities, but the amount was less than control group (P0). P4 had number of stocking at the most which produced large quantities of feces, urine, and residual feed. African catfish excreted ammonia across the gill membranes and a few amounts in urine as a metabolism product (23). Ammonia chemical structure, the length of exposure, $\mathrm{pH}$, and water temperature influenced the ammonia toxicity (23). Ammonia accumulation form its exposure caused intoxication on the central nervous system $(24,25)$. At higher temperature and $\mathrm{pH}$ values, ammonia become more toxic to fish, especially african catfish (23). Nitrobacter administration could compensate the organic waste in the water and improve water quality.

FCR for all treatments were ranged from 0.93 to 1.07 , which the highest FCR obtained in control group where they were only 30 catfish and without any Nitrobacter administration. FCR of P0 was about 1.068; it's meant that African catfish needed around $1.7 \mathrm{~kg}$ of feed to reach $1 \mathrm{~kg}$ fish's total weight. The lowest FCR was obtained by P4 where there were 45 fish with $1 \mathrm{ml}$ Nitrobacter administration. It was about 0.93 which meant that it required $0.93 \mathrm{~kg}$ of food to produce $1 \mathrm{~kg}$ of fish's weight. Recent research explained that FCR below 1.00 affected feed efficiency above $100 \%$ (26). Since organic wastes weren't degraded optimally, these wastes caused high concentration of P0 water due to the accumulation of these wastes. The less optimum environmental condition had effect such as inefficiently converted feed (27). This condition could initiate neuromotors impairments (24). Some diseases 
caused by poor environmental condition lead worse feeding process than the healthy fish (27). Healthy fish normally consumed feed and converted feed in efficient process (27).

Water quality's parameter was also important to be observed (28). DO level was decreased in intervention groups (P1, P2, P3, and P4) because of Nitrobacter administration. Dissolved oxygen is an important parameter because it is needed for the ammonia oxidation process and is a limiting factor for fish survival (7). Low DO concentration could influence the condition of aquatic life (29). The high amount of fish stock in a limited space increased oxygen consumption and metabolic waste product (30). In this study, optimum temperature was $27.2-28.8^{\circ} \mathrm{C}$ for the fish growth. Water temperature becomes the major factor to influence the toxicity of ammonia (31). The temperature for catfish to reach optimum growth is $26-30^{\circ} \mathrm{C}(15,28)$. Increasing water temperature caused higher toxicity of ammonia (32).

Ammonia is one form of $\mathrm{N}$-organic that is harmful to fish (31). Ammonia values in this study ranged from 0.12 to 0.27 $\mathrm{mg} \mathrm{L}^{-1}$. This condition was caused by Nitrobacter activity as an autotrophic nitrifying bacterium that converted ammonia into nitrate. On the other hand, $\mathrm{pH}$ also has important role to fish cultivation (33). However, in this study, $\mathrm{pH}$ value in each group was in fair value which was safe for fish. The optimum pH ranged from 7.5 until $8.5(28,33)$.

The growth of water spinach was observed by measuring the length of water spinach using ruler, also counting the number of leaves. The measurement was conducted at the beginning of study and at the end. During the observation, water spinach growth experienced a significant difference. The lowest growth rate of water spinach was at $\mathrm{P} 0$ which only increased about $5.5 \mathrm{~cm}$. Whereas, the best water spinach growth was found in treatment $\mathrm{P} 4$.

In the treatment of $\mathrm{P} 4$, water spinach growth was 17.5 $\mathrm{cm}$, from $10 \mathrm{~cm}$ to $27.5 \mathrm{~cm}$. These results showed that water spinach in P4 had optimal growth. This was due to the help of Nitrobacter and organic wastes that changed into nitrogen and oxygen, in the aquarium. This component was absorbed by the water spinach roots. Adequate lighting and appropriate spacing also influences the growth. Plant roots need adequate oxygen for respiration so that the absorption of nutrients can be optimal $(34,35)$.

\section{Conclusions}

The administration of Nitrobacter in different aquaponics system with renewable solids had effect on the SGR, SR, and FCR of African catfish (Clarias gariepinus). The best SGR, SR, FCR values were found in treatment 4 with 45 fish stocking densities and the addition of $1 \mathrm{ml}$ Nitrobacter. SGR was $5.05 \%$, SR was $92.77 \%$, and FCR was 0.927. Effective stocking density in the administration of Nitrobacter in aquaponics systems was found in P4 treatment with 45 fish stocking densities and $1 \mathrm{ml}$ Nitrobacter with a concentration of $1 \times 10^{8} \mathrm{CFU} \mathrm{ml}{ }^{-1}$.

\section{Acknowledgements}

A high gratitude to Faculty of Fisheries and Marine, University of Airlangga which has given permission to the authors to use the facility such as laboratory for research purpose.

\section{Conflict of interest}

There are no conflicts of interest regarding the publication of this manuscript.

\section{References}

1. Kementerian Kelautan dan Perikanan Republik Indonesia. Keputusan Menteri Kelautan dan Perikanan Republik Indonesia Nomor 35/Kepmen-KP/2013. 2013.

2. Dinas Perikanan dan Kelautan Jawa Timur. Statistik Perikanan Budidaya Tahun 2014. Surabaya: 2014.

3. Dauda AB, Ajadi A, Tola-Fabunmi AS, Akinwole AO. Waste production in aquaculture: Sources, components and managements in different culture systems. Aquac Fish 2019;4:81-8. doi:10.1016/J.AAF.2018.10.002.

4. Diver S, Rinehart L. Aquaponics - Integration of Hydroponics with Aquaculture. ATTRA Natl Sustain Agric Inf Serv. 2010:1-12.

5. Blidariu F, Grozea A. Increasing the economical efficiency and sustainability of indoor fish farming by means of aquaponics: Review. Anim Sci Biotechnol. 2011;44:1-8.

6. Wang L, Chen X, Guo W, Li Y, Yan H, Xue X. Yield and nutritional quality of water spinach (Ipomoea aquatica) as influenced by hydroponic nutrient solutions with different $\mathrm{pH}$ adjustments. Int J Agric Biol 2017;19:635-42. doi: 10.17957/IJAB/15.0311

7. Effendi $H$, Wardiatno $Y$, Wardiatnomspsplipb Y. Nitrogen removal of aquaculture wastewater in aquaponic recirculation system. Aquac Aquarium. 2015;8(4):491-499.

8. Aquarista F, Iskandar, Subhan U. Pemberian Probiotik dengan Carrier Zeolit pada Pembesaran Ikan Lele Dumbo (Clarias gariepinus). J Perikan Kelaut. 2012;3.

9. Pillay TVR. Aquaculture and the environment. New York: Blackwell; 2004.

10. Ip YK, Chew SF. Ammonia production, excretion, toxicity, and defense in fish: A review. Front Physiol. 2010;1:134. doi: 10.3389/fphys.2010.00134

11. Lewis WM, Yopp JH, Schramm Jr HL, Brandeburg AM, Jr HL. Use of hydroponics to maintain quality of recirculated water in a fish culture system. Trans Am Fish Soc. 1978;107:92-99. Doi: 10.1577/1548$\underline{8659(1978) 107 .}$

12. Yavuzcan YH, Robaina L, Pirhonen J, Mente E, Domínguez D, Parisi G. Fish welfare in aquaponic systems: Its relation to water quality with an emphasis on feed and faeces: A review. Water. 2017;9:13. doi: 10.3390/w9010013.

13. Craig S, Helfrich L. Understanding fish nutrition, feeds, and feeding. Virginia Cooperative Extension. 2017.

14. Mizanur RM, Bai SC. The optimum feeding frequency in growing korean rockfish (Sebastes schlegeli) rearing at the temperature of $15^{\circ} \mathrm{C}$ and $19^{\circ} \mathrm{C}$. Asian Aust J Anim Sci. 2014;27:1319-27. doi: 10.5713/ajas.2014.14193.

15. Kordi MG. Budi Daya Perairan. $2^{\text {nd }}$ ed. Bandung: Citra Aditya Bakti; 2009.

16. Buwono ID. Kebutuhan Asam Amino Esensial Dalam Ransum Ikan. Surabaya: Kanisius; 2000. 
17. Kusriningrum R. Perancangan Percobaan. Surabaya: Airlangga University Press; 2008

18. Hary P, Soedibya T, Listiowati E, Pramono TB, Prayogo NA, Harisam RT. Growth performance of catfish (Clarias gariepenus) cultured of high density with biofloc. System. 2018;02002(2018):1-12. doi:10.1051/e3sconf/20184702002.

19. Wijaya O, Setya Rahardja dan Prayogo B. Pengaruh Padat Tebar Ikan Lele terhadap Laju Pertumbuhan dan Survival Rate pada Sistem Akuaponik. vol. 6. 2014

20. Lisna, Insulistyowati. Potensi Mikroba Probiotik_Fm dalam Meningkatkan Kualitas Air Kolam dan Laju Pertumbuhan Benih Ikan Lele Dumbo (Clarias gariepinus). J Penelit Univ Jambi Seri Sains 2015;17:1-6.

21. Kim DJ, Lee DI, Cha GC, Keller J. Analysis of free ammonia inhibition of nitrite oxidizing bacteria using a dissolved oxygen respirometer. Environ Eng Res. 2008;13(3):125-130. Doi: 10.4491/eer.2008.13.3.125

22. Ahmadi MR, Mehrjand SM, Mahmoudzadeh H, Babaei M. Prediction of survival rate in European white fish (Coregonus lavaretus) fry on three different feeding regimes. Iran J Fish Sci. 2011;10(2):188-202.

23. Levit SM. A Literature Review of Effects of Ammonia on Fish. Montana: 2010. [available here]

24. McKenzie DJ, Shingles A, Claireaux G, Domenici P. Sublethal Concentrations of ammonia impair performance of the teleost fast-start escape response. Physiol Biochem Zool. 2009;82:353-62. doi: $10.1086 / 590218$

25. Randall DJ, Tsui TKN. Ammonia toxicity in fish. Mar Pollut Bull 2002;45:17-23.

26. Putra I, Rusliadi R, Fauzi M, Tang UM, Muchlisin ZA. Growth performance and feed utilization of African catfish Clarias gariepinus fed a commercial diet and reared in the biofloc system enhanced with probiotic. Res. 2017;6:1545. doi: 10.12688/f1000research.12438.1

27. Robinson EH, Li MH. Feed Conversion Ratio for Pond-Raised Catfish. Mississippi: 2015.

28. Ulum MM, Zubaidah M, Arief M. Earth and environmental science the influence of supplemented curcuma in feed formulation to improve growth rate and feed efficiency of catfish (Clarias sp.) 2018;137:12007. doi:10.1088/1755-1315/137/1/012007

29. Prasad BV, Srinivasu P, Varma P, Raman A, Ray S. Dynamics of dissolved oxygen in relation to saturation and health of an aquatic body: A case for Chilka Lagoon, India. J Ecosyst. 2014;2014:1-17. doi: $10.1155 / 2014 / 526245$

30. Moradyan H, Karimi H, Allah Gandomkar H, Reza Sahraeian M, Ertefaat S, Hosseinzadeh Sahafi $\mathrm{H}$. The effect of stocking density on growth parameters and survival rate of rainbow trout alevins (Oncorhynchus mykiss). World J Fish Mar Sci. 2012;4:480-5. doi: 10.5829/idosi.wjfms.2012.04.05.64143

31. Shin KW, Kim SH, Kim JH, Hwang SD, Kang JC. Toxic effects of ammonia exposure on growth performance, hematological parameters, and plasma components in rockfish, Sebastes schlegelii, during thermal stress. Fish Aquat Sci. 2016;19:44. doi: 10.1186/s41240-016-0044-6

32. Barbieri E, Bondioli ACV. Acute toxicity of ammonia in Pacu fish (Piaractus mesopotamicus, Holmberg, 1887) at different temperatures levels. Aquac Res. 2015;46:565-71. doi: 10.1111/are.12203

33. Heydarnejad MS. Survival and growth of common carp (Cyprinus carpio L.) exposed to diff erent water $\mathrm{pH}$ levels. Turkish J Vet Anim Sci. 2012;36:245-9. doi: 10.3906/vet-1008-430.

34. Barberon M, Vermeer JEM, De Bellis D, Wang P, Naseer S, Andersen TG. Adaptation of root function by nutrient-induced plasticity of endodermal differentiation. Cell. 2016;164:447-59. doi: 10.1016/j.cell.2015.12.021.

35. Ryan PR, Delhaize E, Watt M, Richardson AE. Plant roots: Understanding structure and function in an ocean of complexity. Ann Bot. 2016;118:555-9. doi: 10.1093/aob/mcw192

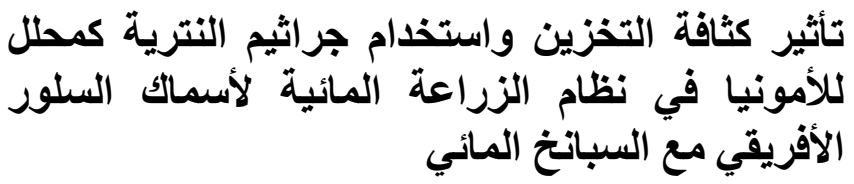

اديندا سبتايساري تراكوستي، برايكو فبكونير و بويدي ستيا رارهردجا

كلية الثروة السمكية والبحرية، جامعة إير لانجا، جاوة الثرقية، إندونيسيا

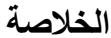

هدفت الدراسة إلى تحديد تأثثر جراثيم النترية على معدل النمو

الخاص، ومعدل البقاء على قيد الحياة، ونسبة تحويل العلف في سمك التك

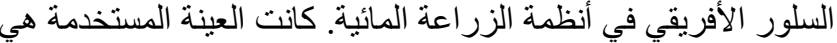

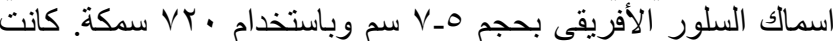
طر ائق البحث المستخدمة معتمدة على التصميم العشو ائي الكامل. تكونت الته

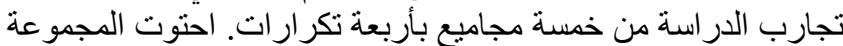

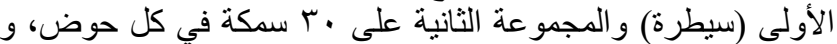

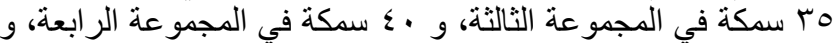

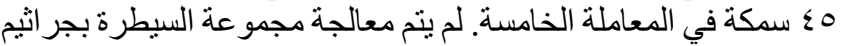

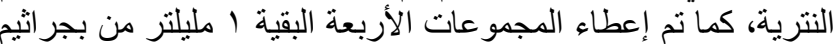

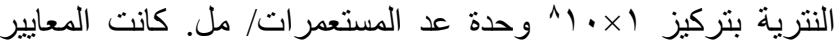

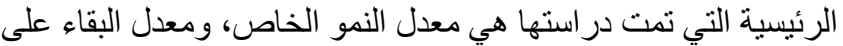

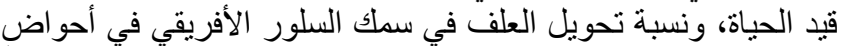

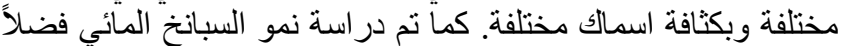

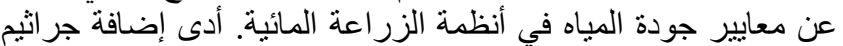

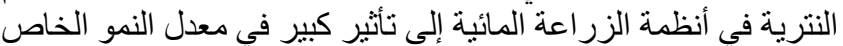

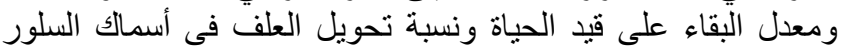

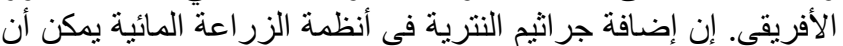

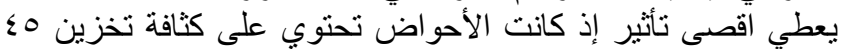

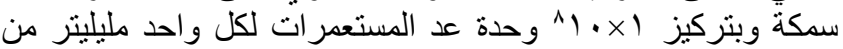
جر اثثم النترية. 